\title{
THE RELATIONSHIP BETWEEN STUDENTS' MOTIVATION AND THEIR LISTENING ACHIEVEMENT AT ENGLISH LANGUAGE EDUCATION STUDY PROGRAM OF KHAIRUN UNIVERSITY
}

\author{
Asrul \\ Dosen Pendidikan Bahasa Inggris, FKIP Universitas Khairun
}

\begin{abstract}
The aims of this research is to find out whether or not there is a significant relationship between students' motivation and their listening achievement. Quantitative method was applied in this research with correlation design. The population of the study was the second semester students of English Language Education Study Program of Khairun University academic year 2016/2017. The sample of this research consisted of 30 students and they were selected by using convenience sampling technique. The data were collected through questionnaire and listening scores. The result of this research shows that $r$ is -0.28. This relationship is small (low) because r value is between 0.10 and 0.29 . The result could be classified that the relationship between the two variables is not significant because the $r$ is small (low). It means that the alternative hypothesis ( $\mathrm{Ha}$ ) stating that there is a significant relationship between students' motivation and their listening achievement is rejected and null hypothesis (Ho) stating that there is no significant relationship between students' motivation and their listening achievement is accepted. This suggests that students with high motivation do not guarantee high achievement in learning listening comprehension.
\end{abstract}

Keyword : Relationship, motivation, listening achievement

\section{INTRODUCTION}

The range of students taking English Study Program as their study of foreign language available in Khairun University has been significantly expanded over the last years. Existing studies in listening in the university are significantly now supplemented with Listening Comprehension 1 (one) until Extensive Listening. Moreover, students should participate in these subjects at the university. In view of this changing educational situation it is interesting to consider students' motivation to learn listening comprehension.

Initially, it may seem leads to educational system in Indonesia took English as Foreign Language (EFL) long time ago, most schools in North Maluku only took general test of English proficiency neither some isolated village nor capital city of North Maluku were not get listening comprehension test when they wanted to enter the school even though went to university with some reasons such as there were not tools and equipment to support listening comprehension test however it was not surprisingly students in university still got lack knowledge about listening comprehension subject. 
Listening is receiving language through ears. Listening involves identifying sounds of speech and processing them into words and sentences. When students listen, they will use their ears to receive individual sounds such as pronunciation, grammar, vocabulary, and meaning. The students will use their brains to convert these into messages that mean something to them. Listening in any language requires focus and attention. It is a skill that some people need to work at harder than others.

Nowadays, every education institution whether state-run or private, army, policeman, doctor who want to get high rank have made rules to take TOEFL (Test of English as Foreign Language) or TOEFL Prediction Test (TPT) and they include listening comprehension as one qualification to enter them and they have started get motivation not only to be better qualified in their job position but also some students have felt as a challenge to increase their listening comprehension achievement. Thus most students who have started from primary till adults have been sent to courses place to do more preparation and listening comprehension that every student need to study hard therefore teachers and lecturers have tried hard to find out possible ways in order to help students listen successfully. Since motivation plays an important role in listening comprehension learning, it is necessary to find out educational system and foreign experience on listening comprehension motivation and to evaluate the relationship between motivation and achievement.

Students who have difficulty concentrating are typically poor listeners and lecturers have to know intrinsic motivation from students in learning listening comprehension to increase their motivation in listening skill. Listening in a foreign language requires even greater focus. Like babies, students learn this skill by listening to people who already know how to speak the language. This may or may not include native speakers. For practice, students can listen to live or record their voices. The most important thing is to listen to a variety of voices as often as they can. To become a fluent speaker in English, students need to develop strong listening skills.

\section{A. Listening}

The importance of listening in language learning can hardly be overestimated. Through perception, we internalize linguistic information without which we can produce language. In the classroom, students always do more listening than speaking. Listening competence is universal "larger" than speaking competence. According to Rost in Gilakjani and Ahmadi (2009, p.978) listening as a process of receiving what the speaker actually says, constructing and representing meaning and empathy.

Based on the explanation above it can be concluded that listening is such a kind of skill which students really need more practice every time to build their listening competence. 


\section{B. Listening Comprehension}

The term "listening comprehension" has been defined by different experts. Hamouda in Gilakjani and Ahmadi (2013, p.8) defined listening comprehension as an interactive process in which listeners are involved in constructing meaning. Based on the explanation above, it can be concluded that listening comprehension is the one of important skill which students need to upgrade every time especially for language learner in order to build their speaking getting better. There are many process through students study listening comprehension because they are not only listen to the recorded which is from lower level to the higher similar to short conversation until discourse but also need to comprehend whether it is a letter, term, punctuation, or meaning and students need to guess what speaker said in the next line.

\section{Motivation}

Dörnyei in Pineda (2016, p. 31) concludes that motivation is responsible for why the people decide to do something, how long they are willing to sustain the activity, and how hard they are going to pursue it. Similarly, Gardner in Pineda (2016, p. 31) explains that motivation is a construct that is difficult to define, but he identifies characteristics that motivated individuals display.

To sum up, it is not surprising to see employers, teachers, and parents trying to find effective methods to motivate their workers, and children. This leads to Dörnyei that it is very important university students need to measure their motivation whereas intrinsic or extrinsic motivation hence in process of study so, they will know what they should do if they lost their mood or spirit for studying especially in learning English in listening comprehension subject.

In relation to the first conceptualization, they said that:

Many early psychologists drew on the views of such philosophers as Plato and Aristotle and conceived of the mind as comprising knowing (cognition), feeling (emotion), and willing (motivation). The will reflected an individual's desire, want or purpose; volition was the act of using the will.

Pintrich \& Schunk in Pineda (2016, p. 34) explain these concepts by saying that in order to put ideas or intentions into action, students need to make use of mandate, or express consent. When they studied listening comprehension, many words have been concept in their brain. Lecturers should replay more than one times what the speakers said in the recorder to made stimulus and motivate them to analyze what word will be the best answer. That is the way in high level for language learner TOEFL (Test of English as Foreign Language) especially listening comprehension session most of the people still confused to find out the best answer neither do lectures, beside style of spoken language that speakers use because of different pronunciations in each country it also could students express consent to choose the correct answer, some student they have strong self- 
confidence but others feel hesitate to do listening comprehension. This explanation of motivation was difficult to test empirically.

\section{RESEARCH METHODOLOGY}

This research used a quantitative method with correlation research design. This research was held at the second semester of English Language Education Study Program of Khairun University.

Population are composed of the territory generalization object, a subject that has a certain quantity and specific characteristics defined by the research researchers to learn and then drawn conclusions. Sugiyono (2011, p.80-81) stated that population also are a group of individuals or items that shared one or more characteristic from which the data can be gathered and analyzed.

The population of this research was the second semester students of English Language Education Study Program of Khairun University academic year 2016/2017. The total population is 95 students in two classes. Each class consists of 40-48 students. This research applied convenience or opportunity sampling. According to Dornyei $(2007$, p.98), the most common sample type in second language learner research is the 'convenience' or 'opportunity sample', where an important criterion of sample selection is the convenience of the research members of the target population are selected for the purpose of the study if they meet certain practical criteria, such as geographical proximity, availability at a certain time, easy accessibility or the willingness to volunteer. The sample of this research was class B consisting of 30 students, using convenience sampling technique.

The instrument used for this research is questionnaire with close ended response to know students' motivation in learning listening comprehension. Most professional questionnaires are primarily made up of 'closed ended' items, which do not require the respondents to produce any free writing instead, respondents are to choose one of the given alternatives (regardless of whether their prefer to answer is among them). The selected response options can, then, easily be numerically coded and entered into a computer database (Dornyei, 2007, p.19). After that, the researcher took students' final scores of listening comprehension subject to see the relationship with their motivation. The questionnaire on motivation is adapted from Gardner. It consists of 20 items with four options relating to listening comprehension. The items of questionnaire are in Indonesian in order to avoid misunderstanding. Their responses to the questionnaire are then translated into English. The document of listening comprehension achievement was taken from students' scores of the middle test examination of listening comprehension subject.

This research applied Pearson Product Moment Correlation Coefficient with the independent test formula to analyze the data and to know the relationship between students' motivation and their listening achievement using level of significance of 0.05 . The formula is: 


$$
R_{x y}=\frac{N \cdot(2 X Y)-(2 X](2 Y]}{\sqrt{\left[N \cdot \Sigma X^{2}-(\Sigma X)^{2}\right]\left[N \cdot \Sigma Y^{2}-(\Sigma Y)^{2}\right]}}
$$

In calculating the Pearson product-moment coefficient, it calculated how much the two variables covariance with respect to each other, and how much each one varies individually. The first, it multiplied the deviation score for one variable (x) by the deviation score for the other variable (y), then the cross product for each pair of deviation scores (xy). In this research, the $X$ variable is the students' motivation while the Y variable is the students' listening achievement. The sum of these cross products $\left(\sum x y\right)$ provided an overall indication of how much the two variables covariance.

The formula below is to know the steps to analyze research comprehends correlation design. In this case, first thing that really important to do is know the validity of the instrument (Questionnaire) have been given to students. According to Descartes (see Syawal, 2017, p. 21) there are two kinds of variable in total score, dependent and independent variable if the variable I (one) identical dichotomy data, while variable II (two) identical continue data, the correlation technique should be find correlation between variable I and variable II these are correlation technique by serial point which index number of correlation with symbol $\mathrm{r}_{\mathrm{pbi}}$.

$$
\text { 1. } R_{p b i}=\frac{M_{p}-M_{t}}{\operatorname{Svt}} \sqrt{\frac{p}{q}}
$$

Explanation:

$$
\begin{array}{ll}
\mathrm{Rpbi} & \text { : by serial point coefficient (validity item coefficient) } \\
\mathrm{M}_{\mathrm{p}} & \text { : mean (testee per items have been answer) } \\
\mathrm{M}_{\mathrm{t}} & \text { : total score } \\
\mathrm{P} & \text { : right items } \\
\mathrm{q} & \text { : wrong items }
\end{array}
$$

2. $M t=\frac{\sum x_{1}}{N}($ counting mean from the total score $)$

Explanation:

$\Sigma \mathrm{Xt} \quad$ : total score each participants

$\mathrm{N} \quad$ : total participants

3. $\mathrm{SDt}=\sqrt{\frac{\mathrm{\Sigma Nt^{2 }}}{\mathrm{N}}}-\left(\frac{\sum \mathrm{N}^{2} \mathrm{t}}{\mathrm{N}}\right)^{2}$ (counting total standard deviation) 
Explanation:

$\Sigma$ : Total participants answer each number

$\Sigma$ : Total result participant answer

Note:

Coefficient correlation connect with " $r$ " table in Person product moment and Likert scale for the level of significance of $5 \%$ and $1 \%$ is:

Rt level of significance 5\% $=0.444$ (Likert scale)

$\mathrm{R}_{\mathrm{t}}$ level of significance $1 \%=0.561$

This research used Likert scale as the level of significance of 0.4 to calculate the validity of instrument. Pallant (2013, p. 139) indicates that the correlation is small (low) if $r=0.10$ to 0.29 , medium (moderate) if $r=0.30$ to 0.49 and large (high) if $r=0.50$ to 1.0. In this case, final score of Listening Comprehension for each students will be analyze to know whether significant relationship between motivation and their listening achievement or not.

\section{FINDINGS AND DISCUSSION}

\section{A. Findings}

After conducting the research, the researcher analyzed the motivation scores taken from the questionnaire. The researcher used the formula to obtain the score of questionnaire, as follows:

\begin{tabular}{ccc}
\hline Option & Score & Description \\
\hline A & 4 & SA x 4 \\
B & 3 & SA x 3 \\
C & 2 & SA x 2 \\
D & 1 & SA x 1 \\
\hline
\end{tabular}

MS $=$ Sum of the total score $(\mathrm{A}+\mathrm{B}+\mathrm{C}+\mathrm{D})$

Note: $\quad \mathrm{SA}=$ Students' answer

MS = Total coding motivation

From the formula above, the result of students' motivation could be obtained.

\section{The Students' Coding of Motivation}

In the questionnaire, each student answered an extrinsic motivation. The data of the students 


\begin{tabular}{|c|c|c|c|c|c|c|c|c|c|c|}
\hline \multirow[b]{2}{*}{ No } & \multirow[b]{2}{*}{$\begin{array}{c}\text { Responde } \\
\text { nts }\end{array}$} & \multicolumn{4}{|c|}{$\mathbf{N}$} & \multicolumn{4}{|c|}{ Score } & \multirow{2}{*}{$\begin{array}{c}\text { Coding } \\
\text { Motivation }\end{array}$} \\
\hline & & $\begin{array}{l}\text { Alway } \\
\text { s/Stro } \\
\text { ngly } \\
\text { Agree }\end{array}$ & $\begin{array}{l}\text { Often/ } \\
\text { Slightly } \\
\text { Agree }\end{array}$ & $\begin{array}{l}\text { Sometimes/ } \\
\text { Slightly } \\
\text { Disagree }\end{array}$ & $\begin{array}{l}\text { Never/ } \\
\text { Strongly } \\
\text { Disagree }\end{array}$ & 4 & 3 & 2 & 1 & \\
\hline 1 & NMZ & 16 & 4 & 6 & 4 & 64 & 12 & 12 & 4 & 92 \\
\hline 2 & MA & 17 & 6 & 6 & 1 & 68 & 18 & 12 & 1 & 99 \\
\hline 3 & NB & 8 & 13 & 6 & 3 & 32 & 39 & 12 & 3 & 86 \\
\hline 4 & IER & 13 & 6 & 6 & 5 & 52 & 18 & 12 & 5 & 87 \\
\hline 5 & NM & 13 & 6 & 11 & 0 & 52 & 18 & 22 & 0 & 92 \\
\hline 6 & DYD & 17 & 8 & 1 & 4 & 68 & 24 & 2 & 4 & 98 \\
\hline 7 & DSM & 12 & 8 & 5 & 5 & 48 & 24 & 10 & 5 & 87 \\
\hline 8 & CK & 18 & 8 & 0 & 4 & 72 & 24 & 0 & 4 & 100 \\
\hline 9 & USK & 14 & 8 & 2 & 6 & 56 & 24 & 4 & 6 & 90 \\
\hline 10 & WAG & 13 & 2 & 9 & 6 & 52 & 6 & 18 & 6 & 82 \\
\hline 11 & RRD & 17 & 2 & 4 & 7 & 68 & 6 & 8 & 7 & 89 \\
\hline 12 & MWG & 17 & 5 & 6 & 2 & 68 & 15 & 12 & 2 & 97 \\
\hline 13 & MABD & 25 & 3 & 0 & 2 & 100 & 9 & 0 & 2 & 111 \\
\hline 14 & DM & 10 & 6 & 9 & 5 & 40 & 18 & 18 & 5 & 81 \\
\hline 15 & SHS & 16 & 9 & 3 & 2 & 64 & 27 & 6 & 2 & 99 \\
\hline 16 & NM & 20 & 5 & 3 & 2 & 80 & 15 & 6 & 2 & 103 \\
\hline 17 & $\mathrm{SN}$ & 16 & 6 & 5 & 3 & 64 & 18 & 10 & 3 & 95 \\
\hline 18 & MAR & 19 & 1 & 3 & 7 & 76 & 3 & 6 & 7 & 92 \\
\hline 19 & $\mathrm{AU}$ & 16 & 7 & 6 & 1 & 64 & 21 & 12 & 1 & 98 \\
\hline 20 & TB & 19 & 6 & 2 & 3 & 76 & 18 & 4 & 3 & 101 \\
\hline 21 & AUM & 11 & 12 & 3 & 4 & 44 & 36 & 6 & 4 & 90 \\
\hline 22 & SM & 7 & 9 & 9 & 5 & 28 & 27 & 18 & 5 & 78 \\
\hline 23 & AWB & 12 & 14 & 2 & 2 & 48 & 42 & 4 & 2 & 96 \\
\hline 24 & MLB & 18 & 3 & 3 & 6 & 72 & 9 & 6 & 6 & 93 \\
\hline 25 & WSI & 14 & 10 & 2 & 3 & 56 & 30 & 4 & 3 & 93 \\
\hline 26 & $\mathrm{RM}$ & 14 & 7 & 6 & 3 & 56 & 21 & 12 & 3 & 92 \\
\hline 27 & INY & 8 & 7 & 6 & 9 & 32 & 21 & 12 & 9 & 74 \\
\hline 28 & SU & 18 & 6 & 3 & 3 & 72 & 18 & 6 & 3 & 99 \\
\hline 29 & NSY & 22 & 4 & 2 & 2 & 88 & 12 & 4 & 2 & 106 \\
\hline 30 & $\mathrm{HH}$ & 10 & 14 & 4 & 2 & 40 & 42 & 8 & 2 & 92 \\
\hline & Total & 450 & 205 & 133 & 111 & 1,800 & 615 & 266 & 111 & 2,792 \\
\hline & Average & 15 & 6.833333333 & 4.433333333 & 3.7 & 60 & 20.5 & 8.87 & 3.7 & 93.06666667 \\
\hline
\end{tabular}

Table 1 shows that in motivation, one student obtained coding of 74 , one student obtained coding of 78 , twenty five students obtained coding of more than 80 and four students obtained coding of more than 100 . So, it can be concluded that the students' motivation in learning Listening Comprehension subject is high. 


\section{The Correlation between Motivation and Listening Scores}

The analysis was carried out the relationship between motivation and listening scores to see whether significant or not. The data were analyzed by using Pearson Product Moment formula at the level of 0.05 . The formula is as follows:

$$
\mathrm{R}_{\mathrm{Xy}}=\frac{\mathrm{N} \cdot\{\Sigma X Y)-\left(\sum X\right](2 Y]}{\sqrt{\left[N \cdot \Sigma X^{2}-(\Sigma X)^{2}\right]\left[N \cdot \sum Y^{2}-(\Sigma Y)^{2}\right]}}
$$

Where:

$$
\begin{array}{ll}
\mathrm{X} & =\text { Coding Motivation } \\
\text { Scores } \mathrm{Y} & =\text { Listening scores } \\
\mathrm{N} & =\text { Total respondents } \\
\Sigma \mathrm{X} & =\text { Total coding motivation scores } \\
\Sigma \mathrm{Y} & =\text { Total listening scores } \\
\Sigma \mathrm{X}_{2} & =\text { Total quadrate coding motivation scores } \\
\Sigma \mathrm{Y}_{2} & =\text { Total quadrate listening scores }
\end{array}
$$

\begin{tabular}{|c|c|c|c|c|c|c|}
\hline No & Respondents & $\mathrm{X}$ & $\mathrm{Y}$ & $X^{2}$ & $\mathrm{Y}^{2}$ & $X Y$ \\
\hline 1 & NMZ & 92 & 50 & 8,464 & 2,500 & 4,600 \\
\hline 2 & MA & 99 & 75 & 9,801 & 5,625 & 7,425 \\
\hline 3 & NB & 86 & 69 & 7,396 & 4,761 & 5,934 \\
\hline 4 & IER & 87 & 51 & 7,569 & 2,601 & 4,437 \\
\hline 5 & NM & 92 & 57 & 8,464 & 3,249 & 5,244 \\
\hline 6 & DYD & 98 & 56 & 9,604 & 3,136 & 5,488 \\
\hline 7 & DSM & 87 & 75 & 7,569 & 5,625 & 6,525 \\
\hline 8 & CK & 100 & 63 & 10,000 & 3,969 & 6,300 \\
\hline 9 & USK & 90 & 50 & 8,100 & 2,500 & 4,500 \\
\hline 10 & WAG & 82 & 75 & 6,724 & 5,625 & 6,150 \\
\hline 11 & RRD & 89 & 51 & 7,921 & 2,601 & 4,539 \\
\hline 12 & MWG & 97 & 50 & 9,409 & 2,500 & 4,850 \\
\hline 13 & MABD & 111 & 56 & 12,321 & 3,136 & 6,216 \\
\hline 14 & DM & 81 & 81 & 6,561 & 6,561 & 6,561 \\
\hline 15 & SHS & 99 & 38 & 9,801 & 1,444 & 3,762 \\
\hline 16 & NM & 103 & 75 & 10,609 & 5,625 & 7,725 \\
\hline 17 & $\mathrm{SN}$ & 95 & 50 & 9,025 & 2,500 & 4,750 \\
\hline 18 & MAR & 92 & 38 & 8,464 & 1,444 & 3,496 \\
\hline 19 & $\mathrm{AU}$ & 98 & 33 & 9,604 & 1,089 & 3,234 \\
\hline 20 & $\mathrm{~TB}$ & 101 & 51 & 10,201 & 2,601 & 5,151 \\
\hline
\end{tabular}

Table 4 below shows the scoring of motivation and listening scores obtained by students (respondents).

Table 4 Correlation of Students' Coding Motivation in Questionnaire and Listening Score. 


\begin{tabular}{ccccccc}
21 & AUM & 90 & 51 & 8,100 & 2,601 & 4,590 \\
22 & SM & 78 & 38 & 6,084 & 1,444 & 2,964 \\
23 & AWB & 96 & 56 & 9,216 & 3,136 & 5,376 \\
24 & MLB & 93 & 63 & 8,649 & 3,969 & 5,859 \\
25 & WSI & 93 & 75 & 8,649 & 5,625 & 6,975 \\
26 & RM & 92 & 69 & 8,464 & 4,761 & 6,348 \\
27 & INY & 74 & 81 & 5,476 & 6,561 & 5,994 \\
28 & SU & 99 & 56 & 9,801 & 3,136 & 5,544 \\
29 & NSY & 106 & 38 & 11,236 & 1,444 & 4,028 \\
30 & HH & 92 & 29 & 8,464 & 841 & 2,668 \\
Total & $\mathrm{N}=30$ & $\sum \mathrm{X}=2,792$ & $\sum \mathrm{Y}=1,700$ & $\sum \mathrm{X}^{2=261,746}$ & $\sum \mathrm{Y}^{2=} 102,610$ & $\sum \mathrm{XY}=157,233$ \\
\hline
\end{tabular}

$$
\begin{aligned}
R_{x y} & =\frac{30(157.253]-(2.792)(1.700)}{\sqrt{\left[30(261.746)-(2.792)^{2}\right]\left[30(102.610)-(1.700)^{2}\right]}} \\
R_{x y} & =\frac{(4.716 .990]-[4.746 .400)}{\sqrt{[(7.852 .380)-(7.795 .264)][(3.078 .300)-(2.890 .000)]}} \\
R_{x y} & =\frac{-2 y .410}{\sqrt{[57.116][188.300]}} \\
R_{x y} & =\frac{-2 y .410}{\sqrt{10.754 .942 .800}} \\
R_{x y} & =\frac{-2 y .410}{1 \text { WS.7v6.04 }} \\
R_{x y} & =-0.28
\end{aligned}
$$

\section{Hypothesis Testing}

To find out the significant relationship between students' motivation and their listening achievement the researcher computed the (r) and confirmed with the value of $r$ at the significant level of $0.05(0.444)$ and of $0.01(0.561)$. It was found that $\mathrm{r}$ is -0.28 . It means that the alternative hypothesis ( $\mathrm{Ha})$ stating that there is a significant relationship between students' motivation and their listening achievement is rejected and null hypothesis (Ho) stating that there is no significant relationship between students' motivation and their listening achievement is accepted at the level of significance of 0.05 . 


\section{B. Discussion}

It was found that the relationship between students' motivation and their listening achievement cannot significantly. This finding is out line with what Fida and Davindra (2016) and Shiu-chen Hsu (2015) have indicated. As Brown (2001, p. 75) says that an integrative orientation have done by Gardner simply means students pursuing a second language for social or cultural purposes, and within that purpose, a teamer could he driven by a high level of motivation or a low level likewise in an instrumental orientation, students' are studying a language in order to further a career or academic goal. The intensity or motivation of a student to attain that goal could be high or low. This statement explain that the intrinsic and extrinsic motivation are two different cases, it would be not make confuse they are separate issues. Students' need both side whether intrinsic or extrinsic motivation to increase their listening achievement because listening is the very important one of four skills, listening should be mastered not only for students but also for the lecturers especially for listening comprehension subject.

In addition the finding of this research confirms Pallant (2013, p. 139) indicates that the correlation is small (low) if $r=0.10$ to 0.29 because the Rxy value is $(-0.28)$. The result $\mathrm{Rxy}<\mathrm{r}=(-0.28<0.29)$ could be classified that correlation between the two variables is small (low). This suggests that there is a relationship between students' motivation and their listening achievement but it is not significant.

\section{CONCLUSION}

From the data analysis, it can be concluded that the relationship between students' motivation and their listening achievement at English Language Education Study Program of Khairun University is not significant. It was evident that the result of coding motivation higher than listening scores, $r$ value $(-0.28)$ at the significant level of 0.05 . The correlation is small (low) if $r=0.10$ to 0.29 because the $r$ is $(-0.28)$. The result could be classified that the correlation between the two variables is small (low). It means that the alternative hypothesis (Ha) stating that there is a significant relationship between students' motivation and their listening achievement is rejected and null hypothesis (Ho) stating that there is no significant relationship between students' motivation and their listening achievement is accepted. This suggests that students with high motivation do not guarantee high achievement in learning listening comprehension. 


\section{REFERENCES}

Ahmadi, M. S. (2016). The Importance of Listening Comprehension in Language Learning. International Journal of Research in English Education, 7-10.

Syawal, Asrul M. (2017). Handout Statistic for Education: Basic Statistical Concept in Education. Ternate: Khairun University.

Brown, H. D. (2002). Teaching by principles second edition: an interactive approach to language pedagogy. NJ: Prentuce Hall: Englewood Cliffs.

Creswell, W. J. (2012). Educational Research: planning fourth edition, conducting and evaluating quantitative and qualitative research. United State of America: Pearson Education.

Deci and Ryan in Dornyei, Zoltan. (1994). Motivation and Motivating in Foreign Language Classroom. The Modern Language Journal, 273-284.

Dornyei, Z. (1994). Motivation and Motivating in Foreign Language Classroom. The Modern Language Journal, 273-284.

Dornyei, Z. (2011). Research Appled in Linguistic. New York: Oxford University Press.

Gilakjani, P. A. (2016). Learners' Listening Comprehension Difficulties in English Language Learning: A Literature Review . Canadian Center of Science and Education, 123-129.

Hsu, S.-c. (2015). A Study of Learning Motivation in English Listening Comprehension. Department of Applied Foreign Languages. Nanya Institute of Technology, 166-177.

Pallant. (2001). SPSS Survival Manual. Buckingham: Open University Press.

Pineda, A. S. (2011). Attitude, Motivation, and English Language Learning . Electronic Dissertation, 31-42.

Asrul M. Syawal. (2017). Statistic For Education. Ternate: Khairun University.

Sacriroban, A. (1999). The Teaching of Listening. TESL Journal, 1-10.

Sugiyono, P. D. (2011). Metode Penelitian Pendidikan: Pendekatan Kuantitatif, Kualitatif, dan $R \& D$. Bandung: Alfabeta. 